\title{
PEMODELAN SPASIAL RESILIENSI EKOSISTEM GUNUNGAPI MERAPI PASCA ERUPSI
}

\section{EMMA SORAYA*, WAHYU WARDHANA, \& RONGGO SADONO}

\author{
Departemen Manajemen Hutan, Fakultas Kehutanan, Universitas Gadjah Mada, \\ Jl. Agro No. 1, Bulaksumur, Sleman, 55281 \\ *Email: esoraya@ugm.ac.id
}

\begin{abstract}
The ability of volcano ecosystem to recover post an eruption to the pre eruption status is affected by its ecological resilience. Resilience of an ecosystem can be defined as the ability of an ecosystem to bounch back after (a) disturbance(s). This study aimed to model spatial resilience of Merapi volcano ecosystem within the area of National Park of Merapi Volcano (TNGM) five years post 2010 eruption and restoration intervention. Analysis was conducted using multi temporal remote sensing and spatial analysis using geographic information system to draw the changes of the ecosystem over time, particularly post eruption and restoration actions. The modelling resulted that five years post eruption, there was resilience transisition/ recovery in volcano ecosystem in TNGM post 2010 eruption. The resilience was shown by the changes from open area to vegetation covers as grass, shrubs, and secondary forests. The transitions occured in term of natural succession as well as human intervention in restoration programs. However, the success of restoration actions to recover the ecosystem to the pre eruption status was not always able to be detected within the period of five years post eruption.
\end{abstract}

Keywords: spatial resilience, Merapi Volcano, remote sensing, multi temporal, geographic information system.

\section{INTISARI}

Kemampuan ekosistem hutan di wilayah gunungapi pasca erupsi dapat kembali berfungsi seperti sebelumnya sangat dipengaruhi oleh resiliensi atau daya lentur/lembam ekosistem tersebut. Resiliensi suatu ekosistem dalam studi ini didefinisikan sebagai kemampuan ekosistem untuk bangkit kembali setelah guncangan/gangguan. Tujuan penelitian ini adalah untuk memodelkan sebaran resiliensi spasial ekosistem hutan di kawasan Taman Nasional Gunung Merapi (TNGM) lima tahun pasca erupsi dan intervensi restorasi. Analisis dilakukan dengan pendekatan penginderaan jauh multi temporal dan analisis spasial menggunakan sistem informasi geografis untuk menggambarkan perubahan kondisi ekosistem gunungapi sebelum dan pasca erupsi dan kegiatan restorasi. Hasil pemodelan menunjukkan bahwa setelah lima tahun pasca erupsi, telah terjadi transisi resiliensi/perbaikan ekosistem dari lahan terbuka ke lahan dengan tutupan vegetasi berupa rumput, semak belukar, dan hutan sekunder. Transisi resiliensi ini terjadi baik secara suksesi alami maupun campur tangan manusia dalam bentuk tindakan restorasi. Salah satu catatan hasil dari penelitian ini antara lain adalah keberhasilan kegiatan restorasi untuk mengembalikan kondisi ekosistem seperti sebelum erupsi tidak selalu dapat dideteksi dalam jangka lima tahun setelah erupsi.

Kata kunci: resiliensi spasial, Gunungapi Merapi, penginderaan jauh, multi temporal, sistem informasi geografis. 


\section{PENDAHULUAN}

Erupsi gunungapi merupakan bencana/kerusakan alam dengan konsekuensi kerusakan yang bervariasi dan kompleks. Erupsi menciptakan mosaik kerusakan yang merupakan variasi respon biotik terhadap aktivitas gunungapi. Perilaku tanaman pionir memenuhi permukaan lahan gunungapi pasca erupsi menunjukkan pola-pola suksesi yang berbeda. Mekanisme yang membentuk pola-pola suksesi ekosistem hutan di wilayah sekitar gunungapi dan kemampuannya untuk berfungsi kembali setelah terjadinya erupsi dipengaruhi oleh resiliensi ekosistemnya. Gunderson (2000) menyebutkan bahwa di tahun 1973, C.S. Holling memperkenalkan kata resiliensi dalam pustaka ekologi sebagai suatu cara untuk memahami dinamika non-linier yang dapat diamati dalam sebuah ekosistem. Resiliensi ekologi didefinisikan sebagai besarnya gangguan yang dapat diantisipasi oleh suatu ekosistem tanpa mengubah proses-proses dan struktur ekosistemnya (Gunderson, 2000). Resiliensi ekosistem juga didefinisikan sebagai kemampuan ekosistem untuk bangkit kembali setelah mengalami gangguan besar (Brand dan Jax, 2007). Resiliensi spasial merujuk pada variasi spasial, dalam hal lokasi, konteks, konektivitas, dan sebaran, yang mempengaruhi dan dipengaruhi oleh resiliensi suatu ekosistem (Cumming, 2011).

Pada saat ini, metode penilaian resiliensi ekosistem masih dalam tahap awal pengembangan. Meskipun teori resiliensi ekosistem sudah lama dikembangkan sejak tahun 1970-an, kuantifikasi resiliensi ekosistem masih belum digunakan dalam kajian ekosistem gunungapi pasca erupsi. Teori dan aplikasi resiliensi spasial lebih banyak diaplikasikan dalam kajian di ekosistem perairan baik di darat maupun di laut, misal: degradasi dan resiliensi terumbu karang dan danau pada skala spasial dan temporal (Carpenter dan Brock, 2004; Hughes et al., 2005; Nystrom dan Folke, 2001; Nystrom et al., 2008; Rowlands et al., 2012) dan ekosistem kering/arid (Koppel dan Rietkerk, 2004). Sementara di bidang kehutanan telah diaplikasikan untuk pendeteksian perubahan pola-pola spasial akibat kegiatan manajemen hutan yang berupa pemanenan, pengendalian kebakaran, pembangunan jaringan jalan, dan penggembalaan (Hessburg et al., 1999); penerapan silvikultur (Churchill et al., 2013; Drever et al., 2006; Finegan dan Camacho, 1999); dan simulasi kerusakan dan suksesi pasca kebakaran hutan (He dan Mladenoff, 1999).

Resiliensi ekosistem dapat dimodelkan dan diukur dari berkurang atau bertambahnya luasan tutupan, kerapatan, produktivitas vegetasi atau ukuran-ukuran atribut vegetasi lainnya. Indikator perubahan tutupan dan atribut vegetasi ini dapat dilihat dari karakteristik spektral dan tekstur dari citra satelit dengan analisis penginderaan jauh (PJ) dan sistem informasi geografis (SIG). Integrasi citra multi temporal dan analisis spasial menggunakan PJ dan SIG telah diakui memiliki teknologi yang semakin maju. Integrasi keduanya mampu menyediakan data perubahan tutupan lahan untuk pengelolaan sumberdaya alam dan lahan, dan khususnya dalam pemodelan resiliensi spasial. Citra multi temporal telah dimanfaatkan untuk mendeteksi perubahan-perubahan ekologis yang terjadi pada berbagai ekosistem (misal: Washington-Allen et al., 2008).

Metode deteksi perubahan tutupan/penggunaan lahan dengan penginderaan jauh multi temporal dapat dilakukan dengan dua pendekatan, yaitu analisis perbedaan citra dan analisis perbedaan respon vegetasi (Washington-Allen et al., 2008). Analisis perbedaan citra merupakan dasar visualisasi spasial secara eksplisit. Visualisasi ini dapat 
diwujudkan dalam bentuk pemetaan tutupan lahan antar waktu. Ketika data multi temporal citra satelit tersedia, peta-peta spasial temporal dapat dihasilkan dan dianalisis untuk menunjukkan tren menurun, bertambah maupun tetap untuk masing-masing tutupan lahan beserta di mana lokasi perubahan tutupan tersebut. Deteksi perubahan lahan dapat digunakan untuk menyediakan visualisasi secara eksplisit bagaimana respon vegetasi terhadap gangguan pada setiap periode analisis. Perubahan ekosistem sebagai respon pasca erupsi terjadi dalam proses yang lama dan skala yang luas, sehingga citra multi temporal menjadi sarana yang penting untuk mempelajari perubahan ini.

Analisis perbedaan respon vegetasi atau metode agregasi (Pickup dan Foran, 1987) merupakan deteksi perubahan tutupan/penggunaan lahan yang memanfaatkan nilai rerata dan varians indeks vegetasi. Pasangan nilai ini dapat digambarkan dengan diagram yang menunjukkan 'gerakan' (motion atau trajectory) dari masing-masing status sepanjang waktu analisis (Pickup dan Foran, 1987; Washington-Allen et al., 2008). Diagram ini merupakan plot rerata dan varians dari nilai reflektan indeks vegetasi dari tiap-tiap citra yang digunakan dalam analisis. Ketika rerata reflektan indeks vegetasi tinggi hal ini berarti secara umum wilayah kajian memiliki tutupan vegetasi yang baik. Ketika rerata yang tinggi diikuti dengan nilai varians yang tinggi, hal ini menunjukkan bahwa tutupan wilayah kajian sangat heterogen dengan sebagian besar berupa tutupan lahan bervegetasi.

Klasifikasi penggunaan dan tutupan lahan telah terbukti bermanfaat untuk menggambarkan karakteristik wilayah dan perubahannya dari waktu ke waktu. Perubahan tutupan lahan merupakan interaksi dalam dimensi ruang dan waktu antara dimensi biofisik dan dimensi manusia (human)
(Rindfuss et al., 2004). Pengetahuan mengenai perubahan penutupan lahan penting dalam konteks pengelolaan lingkungan ke depan. Klasifikasi tutupan lahan berbasis objek atau juga dikenal dengan metode segmentasi memiliki keunggulan pada pemisahan antar objek yang akurat dan presisi (Darwish et al., 2003). Klasifikasi ini juga memiliki kelebihan dalam efisiensi waktu pengerjaan. Klasifikasi digital ini dilakukan berdasarkan segmentasi objek, bukan berdasarkan piksel, dengan membagi suatu citra ke dalam sub-sub bagian. Segmentasi yang digunakan untuk mengklasifikasi data citra adalah segmentasi multiresolusi yang secara lokal meminimumkan rata-rata heterogenitas objek-objek pada citra.

Gunungapi Merapi yang bererupsi pada tahun 2006 dan 2010 merupakan salah satu contoh ekosistem gunungapi yang dapat menjadi sumber pelajaran dan pemahaman tentang resiliensi spasial pasca erupsi. Kerusakan yang besar dan tiba-tiba, misal dalam bentuk erupsi, dapat menghilangkan resiliensi suatu eksositem dan menjadikan ekosistem ini bergeser ke kondisi yang lain (Scheffer et al., 2001) menjadikan pemahaman resiliensi spasial ekosistem gunungapi menjadi penting. Pemodelan resiliensi spasial dapat menggambarkan mekanisme perubahan pembentukan lansekap gunungapi setelah terjadinya erupsi. Kompleksnya proses-proses dan fungsi ekosistem menyebabkan upaya restorasi harus dilakukan dengan mengantisipasi perubahan yang mungkin terjadi pada tingkat bentang lahan (landscape/lansekap) agar keutuhan ekosistem dalam memberikan fungsinya tidak terjadi secara parsial (Naveh, 2007). Dengan demikian, pemahaman resiliensi spasial suatu ekosistem juga merupakan syarat mutlak pada strategi pengelolaan ekosistem yang lestari. Del Moral dan Grishin (1999) mereview kemampuan suatu ekosistem gunungapi untuk 
bangkit kembali setelah erupsi namun tidak menggunakan kerangka resiliensi ekosistem.

Tujuan penelitian ini adalah untuk memodelkan sebaran spasial resiliensi ekosistem hutan di kawasan Taman Nasional Gunung Merapi lima tahun pasca erupsi dan intervensi restorasi menggunakan penginderaan jauh multi temporal dan analisis spasial. Pemodelan resiliensi spasial ini diperlukan sebagai salah satu sarana untuk mengukur keberhasilan kegiatan restorasi yang merupakan bentuk intervensi manusia dalam pengembalian fungsi ekosistem gunungapi ke kondisi sebelum terjadinya erupsi. Besar, luas, dan kompleksnya kerusakan pasca erupsi membuat usaha-usaha restorasi memerlukan input yang sangat besar sehingga seringkali usaha restorasi tidak dapat dilakukan dalam skala yang luas dan perlu dievaluasi keberhasilannya. Restorasi ekosistem hutan di wilayah gunungapi menjadi satu langkah penting untuk mengembalikan fungsi-fungsi dalam memberikan layanan untuk unsur-unsur yang ada di dalamnya termasuk manusia, flora, dan fauna yang telah menurun atau hilang sama sekali akibat erupsi.
Resiliensi ekosistem merupakan salah satu komponen penting dalam restorasi ekosistem yang merupakan kunci menuju kelestarian.

\section{BAHAN DAN METODE}

\section{Lokasi penelitian}

Penelitian ini menganalisis perubahan fungsi ekosistem hutan di kawasan Taman Nasional Gunung Merapi (TNGM) dengan memanfaatkan teknologi PJ dan SIG. Peta lokasi penelitian beserta demplot restorasi di Kawasan TNGM dapat dilihat pada Gambar 1.

\section{Data}

Citra Landsat TM, ETM, dan ETM+ dengan tutupan awan paling rendah dipilih dari tahun 2003, 2007, 2009, 2011, dan 2015 (Tabel 1). Dalam penelitian ini preproses tidak dilaksanakan karena software yang digunakan untuk klasifikasi tutupan lahan sudah secara inheren melakukan proses kalibrasi dan citra hanya digunakan sebagai referensi data analisis. Data lain yang digunakan berupa Peta Rupa Bumi Indonesia (RBI) sebagai acuan

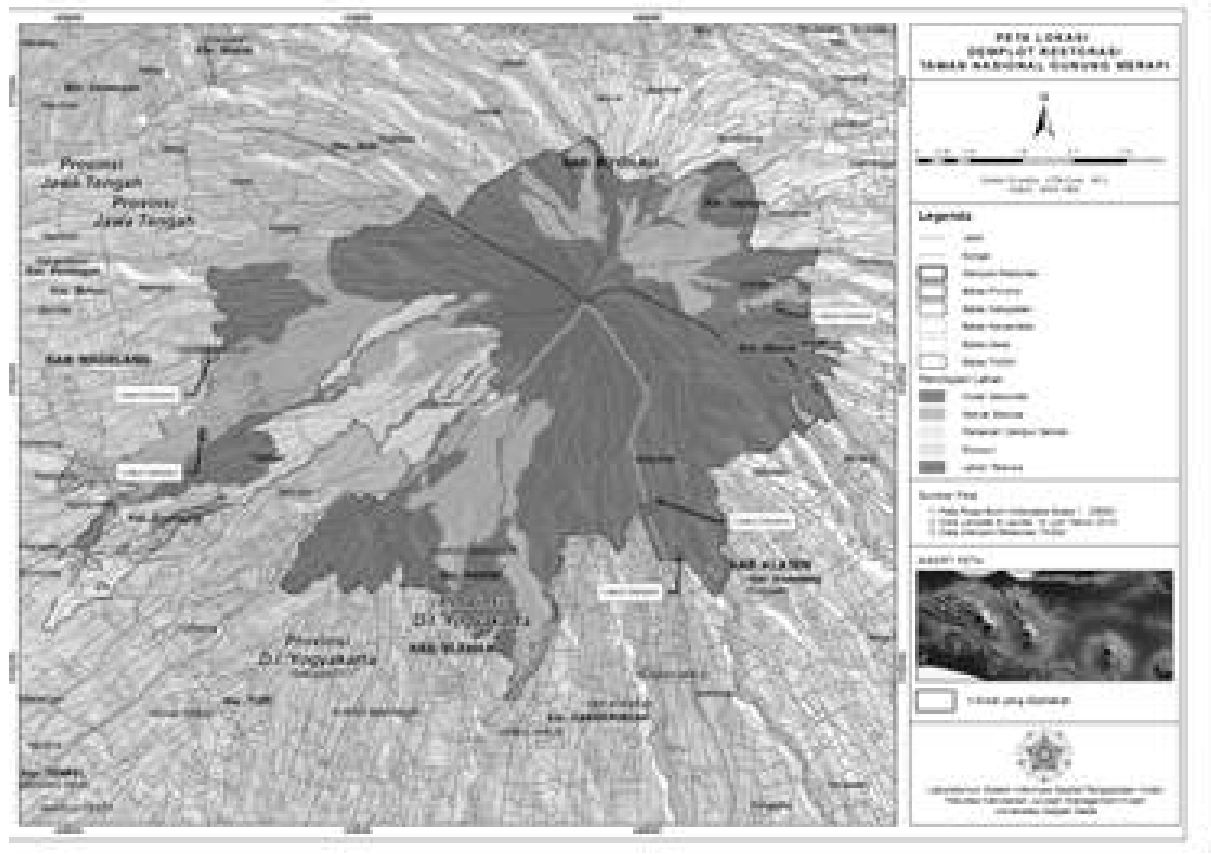

Gambar 1. Peta lokasi penelitian dan demplot restorasi TNGM 
pengunaan dan tutupan lahan dalam analisis penafsiran citra; peta batas kawasan TNGM; dan peta lokasi demplot restorasi. Citra selanjutnya dimasking sesuai dengan batas kawasan TNGM.

Observasi lapangan (ground check) dilaksanakan pada bulan Oktober-November 2015. Tujuan dilaksanakannya observasi lapangan adalah untuk memetakan rujukan kelas-kelas tutupan lahan terkini. Kelas tutupan lahan hasil survei lapangan digunakan sebagai rujukan klasifikasi citra satelit yang diakuisisi tahun 2015 (terkini). Selain itu, observasi lapangan juga ditujukan untuk melihat keberhasilan tindakan restorasi pada demplot restorasi. Demplot restorasi yang diobservasi adalah demplot Kemalang (Kabupaten Klaten) di sisi timur TNGM dan demplot Srumbung (Kabupaten Magelang) di sisi barat TNGM. Keduanya berada dalam wilayah administrasi Propinsi Jawa Tengah. Selama survei lapangan beberapa titik pengamatan di dalam Kawasan TNGM direkam dengan Global Positioning System (GPS). Empat puluh titik pengamatan ditentukan dan disebar secara proporsional menurut luasan tutupan lahan hasil klasifikasi. Penentuan lokasi titik pengamatan dilakukan secara random untuk tiap kelas tutupan lahan.

\section{Penafsiran Citra Penginderaan Jauh/ Klasifikasi Tutupan Lahan}

Penelitian ini melaksanakan penafsiran data PJ multitemporal yang tersedia dengan metode object-based classification (Jensen, 2005) dengan edge algorithm (Maintz, 2005) menggunakan software ENVI 5.0. Beberapa parameter utama digunakan sebagai pemisah objek, yaitu color, scale, shape, smoothness, dan compactness. Parameter ini digunakan untuk menentukan nilai maksimum heterogenitas yang dibolehkan untuk menghasilkan objek-objek citra sehingga output yang dihasilkan berupa poligon-poligon obyek yang homogen. Fokus dalam proses penafsiran adalah melihat dan mencari tahu tipe penutupan lahan yang bervegetasi kayu. Untuk membedakan lebih lanjut dalam proses klasifikasi berkayu dan tidak berkayu, akan digunakan proses transformasi citra dengan level threshold tertentu untuk membedakan lahan yang berkayu atau tidak berkayu (Wardhana et al., 2011). Berdasar sistem klasifikasi tutupan lahan SNI 7645 (BSN, 2010) dan observasi lapangan lima kelas tutupan lahan digunakan untuk mengklasifikasikan tutupan lahan citra berupa: lahan terbuka, rumput, pertanian campur semak, semak belukar, dan hutan sekunder.

\section{Analisis Transisi/Perubahan Tutupan Lahan}

Perubahan tutupan lahan dianalisis sebagai bukti historis kondisi ekosistem dari waktu ke waktu. Data perubahan tutupan lahan diperoleh dari hasil penafsiran citra multitemporal. Perubahan tutupan lahan dievaluasi dengan komparasi postclassification (Jensen, 2005). Hal ini diperlukan

Tabel 1. Data spasial yang digunakan dalam penelitian

\begin{tabular}{llc}
\hline Tahun & & Tanggal akuisisi \\
\hline 2015 & Citra Landsat8 & 14 Juni 2015 \\
2011 & Citra Landsat TM & 19 Juni 2011 \\
2009 & Citra Landsat TM & 19 Oktober 2009 \\
2007 & Citra Landsat TM & 26 Juli 2007 \\
2003 & Citra Landsat ETM & 20 Mei 2003 \\
1997 & Peta rupa bumi Jawa Tengah dan DIY & \\
1997 & Peta administrasi Jawa Tengah dan DIY & \\
2004 & Peta batas kawasan TNGM & \\
2014 & Peta zonasi TNGM & \\
\hline
\end{tabular}


untuk melihat perbedaan lebih rinci pada penutupan lahan yang mengalami transisi dengan kondisi bentang lahan setempat. Dalam konteks ini bentang lahan Gunungapi Merapi disederhanakan berdasarkan tutupan lahannya. Hasil dari analisis ini dapat diringkas dalam bentuk sebuah tabel matriks perubahan "dari-menjadi" yang biasa juga disebut sebagai matriks transisi (Jensen, 2005). Matriks ini membandingkan dalam rentang periode secara berseri: sebelum erupsi (tahun 2003 dan 2009), seketika setelah erupsi 2006 dan 2010 (2007 dan 2011) dan beberapa tahun setelah erupsi dan usaha restorasi (2009 dan 2015). Analisis ini dilakukan dengan software ArcGIS 10.3.

\section{Analisis Resiliensi}

Analisis resiliensi ditujukan untuk menilai kelembaman ekosistem pasca gangguan. Penilaian resiliensi pada penelitian ini dilakukan secara kuantitatif dengan menghitung persentase laju transisi dari lahan terbuka menjadi lahan bervegetasi (Hosonuma et al., 2012). Analisis resiliensi berdasar transisi perubahan tutupan lahan juga dianalisis secara agregat (Pickup dan Foran, 1987). Transisi perubahan tutupan lahan di dalam wilayah studi secara agregat digambarkan dalam diagram rerata dan varians dari nilai normalized difference vegetation index (NDVI) dari masing-masing citra yang digunakan. Nilai NDVI digunakan pada analisis resiliensi dikarenakan fokus penelitian ini adalah kemampuan 'kembali'-nya tutupan lahan berupa vegetasi. Vegetasi berbeda dari tutupan lahan lain karena vegetasi cenderung menyerap dengan kuat gelombang merah dari sinar matahari dan merefleksikan (yang ditangkap oleh sensor) gelombang infra merah dekat. Nilai NDVI menggunakan nilai infra merah dekat dan merah yang sangat kuat pantulannya untuk membedakan vegetasi dalam berbagai kondisi, misalnya berupa gangguan atmosfer atau topografik. NDVI dihitung mengikuti rumus Richard (2013).

\section{HASIL DAN PEMBAHASAN}

\section{Penafsiran Citra Penginderaan Jauh}

Peta hasil penafsiran dan klasifikasi tutupan lahan selama periode 2003-2015 berdasar hasil interpretasi masing-masing citra disajikan pada Gambar 2. Luasan masing-masing kelas tutupan lahan pada setiap tahun citra PJ dapat dilihat pada Gambar 3. Uji akurasi dilakukan pada citra tahun 2015 menunjukkan bahwa nilai Kappa yang diperoleh adalah $88 \%$.

\section{Transisi/Perubahan Tutupan Lahan}

Perubahan tutupan lahan di Kawasan TNGM berupa matriks transisi tersaji dalam Gambar 5 . Lebih dari 1.200 ha tutupan hutan sekunder pada periode 2009-2011 berubah menjadi semak belukar atau lahan terbuka seluas hampir 800 ha. Sebaliknya, luasan lahan terbuka menurun cukup banyak pada periode 2011-2015. Pada periode ini hampir 700 ha, lebih dari 230 ha, dan lebih dari 100 ha lahan terbuka secara berturut berubah tutupannya menjadi hutan sekunder, semak belukar, dan rumput.

\section{Resiliensi Spasial TNGM}

Trajectory perubahan tutupan lahan bervegetasi TNGM hasil dari penghitungan laju transisi perubahan tutupan lahan bervegetasi dan nilai rerata dan varians NDVI citra tahun 2003-2015 dapat dilihat secara berturutan pada Gambar 4 dan Gambar 5.

Perubahan/transisi tanah terbuka menjadi hutan sekunder pada masa transisi 2011-2015 menunjukkan persentase tertinggi dibandingkan perubahan ke tutupan lahan bervegetasi yang lain (Gambar 4). Sebaliknya pada masa transisi tahun 2003-2007 dan 
2009-2011 terlihat bahwa tidak banyak perubahan bervegetasi, pada masa ini adalah masa erupsi tutupan dari lahan terbuka menjadi tutupan lahan

Gunungapi Merapi di tahun 2006 dan 2010. Periode
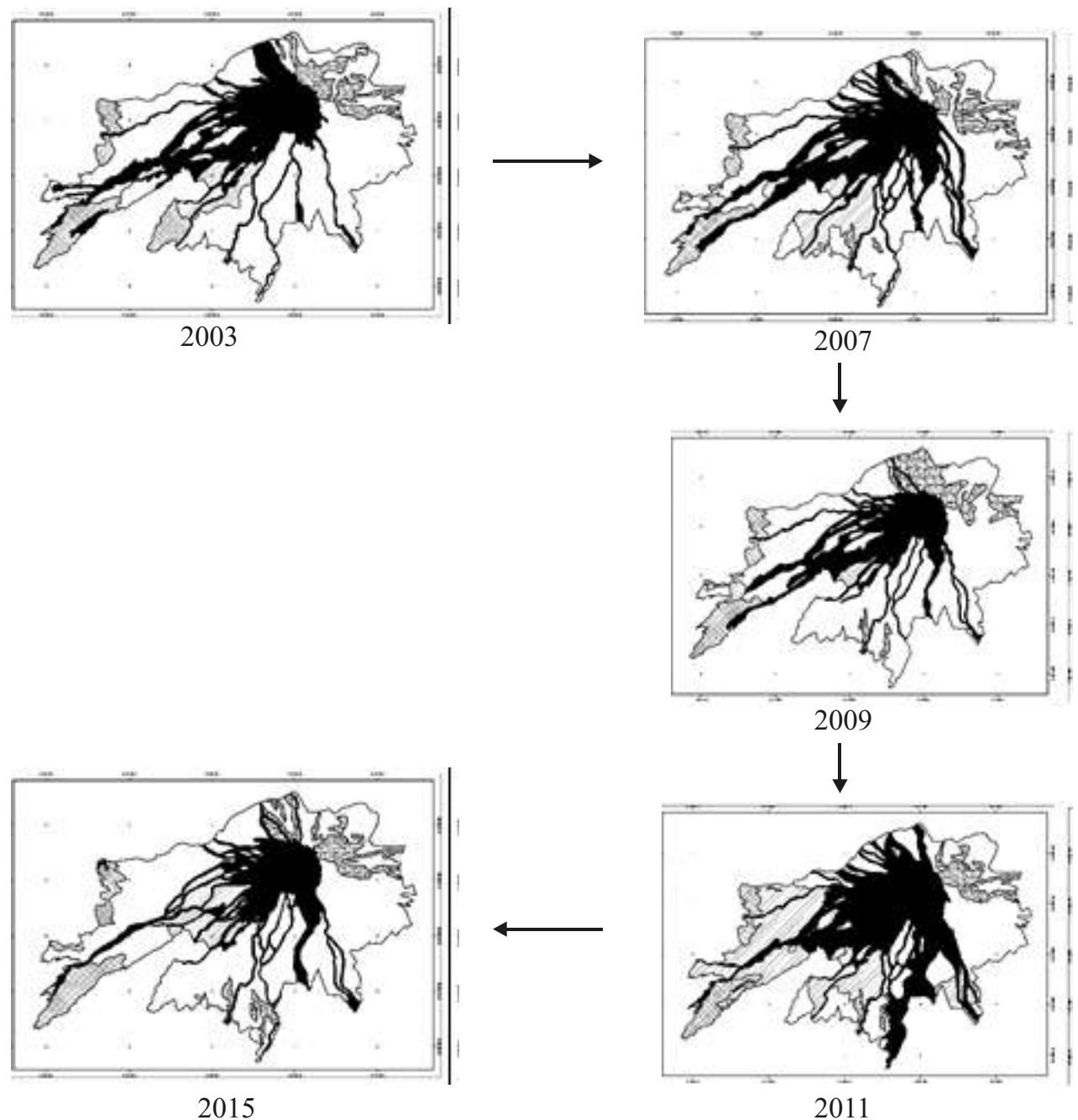

Gambar 2. Peta tutupan lahan hasil penafsiran citra PJ tahun 2003, 2007, 2009, 2011, dan 2015

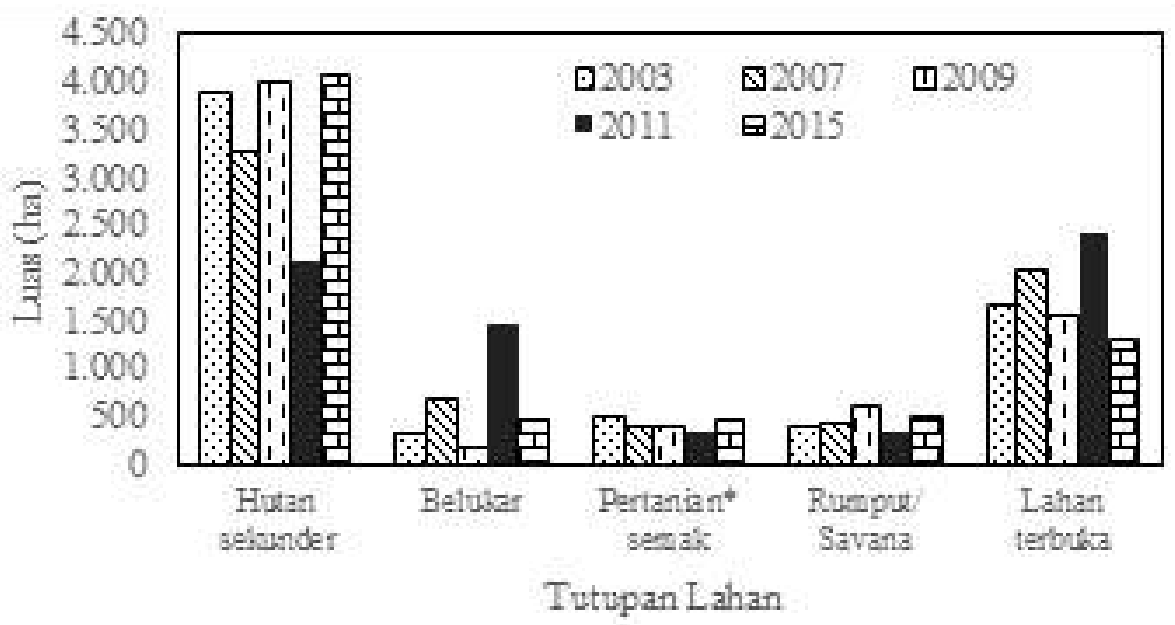

Gambar 3. Luas masing-masing tutupan lahan hasil penafsiran citra 
Tabel 2. Matriks transisi tutupan lahan TNGM periode $2000-2015$

\begin{tabular}{|c|c|c|c|c|c|}
\hline \multicolumn{2}{|c|}{ Tipe transisi } & \multicolumn{4}{|c|}{ Periode dan luas (ha) } \\
\hline Dari & Menjadi & $2003-2007$ & $2007-2009$ & $2009-2011$ & $2011-2015$ \\
\hline \multirow{5}{*}{ hutan sekunder } & hutan sekunder & $2.948,6$ & $2.888,2$ & $1.843,9$ & $2.044,8$ \\
\hline & semak belukar & 333,2 & 16,1 & $1.201,6$ & 28,6 \\
\hline & pertanian*semak & 21,0 & 10,9 & 17,5 & 0 \\
\hline & rumput/savana & 116,0 & 66,8 & 125,8 & 27,4 \\
\hline & lahan terbuka & 438,8 & 47,5 & 777,2 & 13,0 \\
\hline \multirow{5}{*}{ semak belukar } & semak belukar & 235,3 & 91,1 & 74,8 & 84,0 \\
\hline & hutan sekunder & 0 & 549,0 & 14,1 & $1.271,5$ \\
\hline & pertanian*semak & 0 & 1,5 & 0,5 & 71,2 \\
\hline & rumput/savana & 0 & 50,8 & 0 & 1,4 \\
\hline & lahan terbuka & 59,8 & 23,0 & 72,9 & 16,7 \\
\hline \multirow{5}{*}{ pertanian*semak } & pertanian*semak & 321,9 & 324,2 & 313,6 & 329,7 \\
\hline & hutan sekunder & 86,8 & 22,8 & 0 & 6,9 \\
\hline & semak belukar & 54,6 & 0,1 & 25,6 & 0 \\
\hline & rumput/savana & 0 & 0 & 0 & 0 \\
\hline & lahan terbuka & 28,4 & 3,5 & 32,8 & 9,2 \\
\hline \multirow{5}{*}{ rumput/savana } & rumput/savana & 252,0 & 316,2 & 209,4 & 307,5 \\
\hline & hutan sekunder & 102,6 & 136,8 & 243,8 & 27,3 \\
\hline & semak belukar & 0 & 0 & 1,4 & 0 \\
\hline & pertanian*semak & 0 & 0 & 0 & 0 \\
\hline & lahan terbuka & 2,3 & 0,2 & 141,2 & 0,6 \\
\hline \multirow{5}{*}{ lahan terbuka } & lahan terbuka & $1.456,9$ & $1.464,5$ & $1.371,0$ & $1.236,9$ \\
\hline & hutan sekunder & 91,4 & 369,4 & 11,9 & 695,7 \\
\hline & semak belukar & 42,3 & 55,0 & 141,3 & 321,1 \\
\hline & pertanian*semak & 7,7 & 35,4 & 14,2 & 19,0 \\
\hline & rumput/savana & 35,2 & 62,0 & 0,1 & 122,4 \\
\hline
\end{tabular}

erupsi (2006 dan 2010) terjadi banyak perubahan tutupan hutan sekunder menjadi lahan terbuka dan semak belukar. Pada periode berikutnya (2011-2015) terlihat bahwa ekosistem mulai mengalami proses transisi kembali ke keadaan sebelum erupsi dengan indikasi bertambahnya luas perubahan lahan terbuka ke tutupan lahan rumput/savana, semak belukar, dan hutan sekunder.

Gambar 5 menunjukkan bahwa pada tahun 2003 sebagai dasar/baseline kondisi awal sebelum erupsi berulang tahun 2006 dan 2010, memiliki nilai varians NDVI yang relatif lebih tinggi dibanding citra tahun-tahun yang lain. Hal ini mengindikasikan bahwa kondisi tutupan lahan di kawasan TNGM pada tahun 2003 lebih heterogen dibanding tahun-tahun yang lain dan nilai rerata NDVI di tahun 2015 merupakan nilai tertinggi dibanding tahuntahun yang lain. Hal ini mengindikasikan bahwa tutupan lahan berupa vegetasi di kawasan TNGM pada tahun 2015 relatif lebih luas dibanding tahun-tahun yang lain. Nilai varians NDVI tahun 2015 yang relatif kecil menunjukkan bahwa tutupan lahan relatif homogen. Hal ini sejalan dengan hasil interpretasi tutupan lahan di TNGM berdasar citra tahun 2015 yang menunjukkan luasan berupa hutan sekunder lebih luas dari tahun-tahun sebelumnya (Gambar 3). Demikian pula dengan luasan hutan sekunder pada tahun 2015 meningkat dibanding 


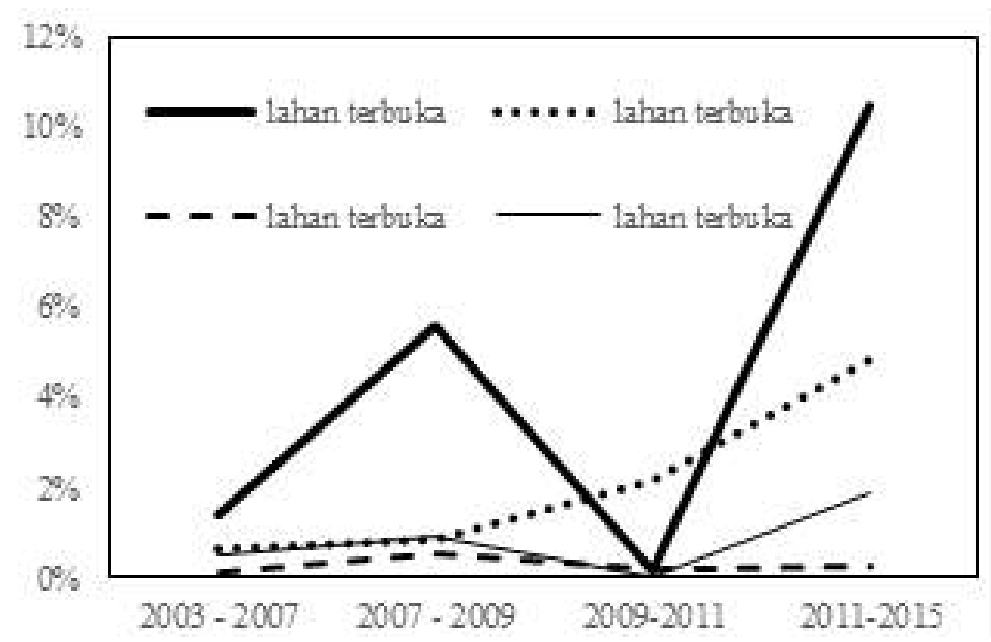

Gambar 4. Transisi tutupan lahan dari lahan terbuka ke tutupan lahan bervegetasi

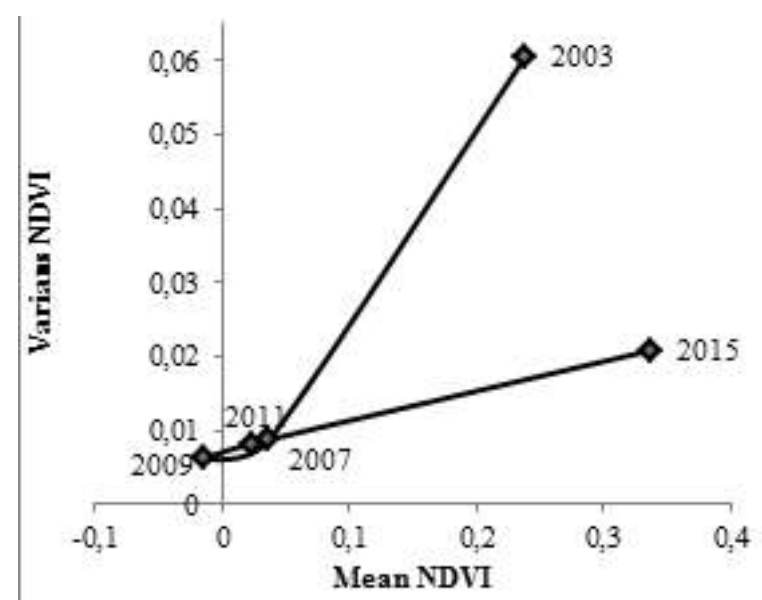

Gambar 5. Diagram perubahan tutupan lahan berdasar nilai rerata dan varians NDVI citra TN Gunungapi Merapi (2003 - 2015)

tahun 2011, namun demikian luasannya belum seluas pada tahun 2003. Terdapat fakta yang menarik dengan citra tahun 2009 (3 tahun setelah erupsi tahun 2006) yang menunjukkan nilai rerata dan varians NDVI yang paling kecil dibandingkan dengan tahun yang lain. Hal ini mengindikasikan bahwa resiliensi setelah 3 tahun erupsi 2006 menunjukkan tutupan lahan yang paling homogen dengan tutupan lahan berupa vegetasi yang paling minimal.

Dari hasil analisis dapat diindikasikan bahwa telah terjadi proses transisi recovery/perbaikan ekosistem dari yang terdampak erupsi menuju ke kondisi sebelumnya/baseline. Hal ini menunjukkan bahwa ekosistem Gunungapi Merapi masih memiliki kelembaman/resiliensi untuk mengembalikan fungsi-fungsi ekosistemnya ke kondisi sebelum terjadinya erupsi. Hanya $12,6 \%$ dari luasan total TNGM yang berupa lahan terbuka selama periode 2007-2009 (pasca erupsi 2006) telah berubah menjadi tutupan bervegetasi berupa rumput, semak belukar, dan hutan sekunder serta lebih dari $28 \%$ untuk periode 2011-2015 (pasca erupsi 2010) (Gambar 4). Laju proses transisi dari lahan terbuka menjadi lahan bervegetasi terbesar terjadi pada periode recovery di mana terjadi transisi dari lahan terbuka menjadi hutan sekunder sebesar 9,3\% dan $17,2 \%$ masing-masing secara berurutan setelah erupsi tahun 2006 (masa transisi 2007-2009) dan setelah erupsi tahun 2010 (masa transisi 2011-2015). Resiliensi pasca erupsi tahun 2006 dapat dikatakan relatif lebih kecil dalam hal ukuran luasan perubahan tutupan lahan dari tanah kosong menjadi tutupan lahan bervegetasi dibandingkan dengan pasca erupsi tahun 2010. Hal ini antara lain mungkin disebabkan lamanya periode pengamatan yang lebih lama untuk pasca erupsi tahun 2010 (4 tahun, citra tahun 2011 dan 2015) dibandingkan dengan pasca erupsi 2006 (2 tahun, citra 2007 dan 2009). 
Kuantifikasi laju recovery setelah adanya gangguan yang dihadapi oleh suatu ekosistem merupakan ukuran damping (Washington-Allen et al., 2008). Damping ini merupakan salah satu dari karakteristik resiliensi ekologi yang definisikan oleh Orians (1975), Westman (1985), Westman dan O'Leary (1986) dalam (Washington-Allen et al., 2008) yang secara harfiah dapat diartikan sebagai laju berkurangnya kerusakan. Adanya proses transisi/recovery dari lahan terbuka menjadi lahan bervegetasi menunjukkan adanya dinamika lahan/suksesi di kawasan TNGM pasca erupsi 2006 dan 2010. Transisi dari lahan terbuka ke lahan bervegetasi pada periode 2007-2009 dan 2011-2015 menunjukkan laju yang lebih besar daripada perubahan tutupan lahan bervegetasi, baik dari rumput ke semak belukar dan hutan sekunder maupun semak belukar ke hutan sekunder.

Mekanisme transisi resiliensi ini dapat berlangsung dengan proses suksesi secara alami maupun melalui intervensi manusia dalam bentuk kegiatan restorasi. Perhatian diperlukan untuk menginterpretasi hasil dari analisis citra multitemporal ini, karena data yang tersedia/lamanya waktu sejak dari erupsi masih sangat pendek. Penelitian ini menunjukan bahwa keberhasilan intervensi dalam bentuk restorasi masih belum sepenuhnya dapat dideteksi dalam jangka waktu yang relatif pendek (5 tahun).

Seperti ditunjukkan pada Gambar 1, demplot restorasi di sisi timur kawasan TNGM relatif menunjukkan keberhasilan dibandingkan dengan demplot restorasi di sisi barat. Di sisi timur pada tahun 2011 banyak areal merupakan lahan terbuka dan pada hasil analisis citra tahun 2015 terlihat pada areal tersebut telah bertransisi menjadi hutan sekunder (Gambar 2). Di sisi barat, areal tersebut pada periode 2011-2015 kondisi tutupan lahannya relatif tetap, yaitu berupa semak belukar (Gambar 2). Fenomena ini dapat terjadi kemungkinan diakibatkan adanya pengaruh sisa debu vulkanik yang ada di sisi timur kawasan yang terdampak erupsi 2010. Di sisi barat kawasan relatif tetap kondisinya karena kerusakan yang terjadi pada areal ini tidak sampai mengubah tutupan lahan dari kondisi sebelum erupsi.

Hal lain yang perlu menjadi perhatian adalah klasifikasi tutupan lahan yang digunakan dalam penelitian ini masih sangat umum dan belum dapat menunjukkan informasi tentang perubahan komposisi spesies. Sangat mungkin terjadi tidak ada perubahan tutupan lahan yang terdeteksi namun terjadi perubahan komposisi spesies yang tidak terdeteksi di areal kajian yang tentu saja akan berakibat berubahnya fungsi ekosistem areal tersebut, misalnya tumbuhnya tanaman-tanaman pionir yang bukan spesies lokal (non-native) dan invasif, misal: Acacia decurens yang banyak ditemui di kawasan TNGM (lihat: Wibowo, 2015). Tanaman ini berpotensi menghambat proses transisi recovery spesies lokal.

\section{KESIMPULAN}

Hasil analisis data penginderaan jauh multitemporal 2003-2015 dan pemodelan spasial, Taman Nasional Gunung Merapi saat ini mengalami masa transisi revegetasi dari lahan terbuka menjadi tutupan berupa rumput, semak belukar, dan hutan sekunder. Pada periode recovery/transisi resiliensi 2007-2009 dan 2011-2015, laju transisi dari lahan terbuka menjadi tutupan bervegetasi masing-masing secara berurutan sebesar $12,6 \%$ dan 28,2\%. Pemodelan spasial juga menunjukkan bahwa percepatan perbaikan/revegetasi/proses transisi resiliensi ekosistem pasca erupsi 2006 dan 2010 di kawasan Taman Nasional Gunungapi Merapi dengan intervensi restorasi tidak selalu dapat dideteksi 
dengan penginderaan jauh maupun secara langsung di lapangan dalam jangka pendek (dua dan lima tahun).

Perlu dilakukan penelitian lanjutan untuk terus memantau perkembangan suksesi kawasan Taman Nasional Gunungapi Merapi pasca erupsi baik di lokasi restorasi maupun lokasi lain (suksesi alami). Penelitian lebih detil menggunakan citra penginderaan jauh dengan resolusi spasial yang lebih tinggi juga diperlukan untuk mendapatkan hasil interpretasi dan analisis yang lebih mendetil apakah ekosistem yang terbentuk pasca erupsi telah benar kembali seperti semula/sebelum erupsi. Penelitian lebih lanjut ini juga dimaksudkan untuk mendeteksi ada tidaknya spesies invasif di dalam kawasan dan menghambat kembalinya spesies lokal.

\section{UCAPAN TERIMA KASIH}

Kami menyampaikan terima kasih kepada Fakultas Kehutanan UGM atas pendanaan untuk penelitian ini; Prof. Wahyu Andayani atas masukan yang konstruktif; dan Agil Tribowo yang membantu dalam penelitian ini.

\section{DAFTAR PUSTAKA}

Brand FS \& Jax K. 2007. Focusing the meaning (s) of resilience: resilience as a descriptive concept and a boundary object. Ecology and Society 12(1), 23.

BSN. 2010. Klasifikasi penutup lahan - SNI 7645.

Carpenter S \& Brock WA. 2004. Spatial complexity, resilience, and policy diversity: Fishing on Lake-Rich Landscapes. Ecology and Society 9(1), 8.

Churchill DJ, Larson AJ, Dahlgreen MC, Franklin JF, Hessburg PF, \& Lutz JA. 2013. Restoring forest resilience: From reference spatial patterns to silvicultural prescriptions and monitoring. Forest Ecology and Management 291, 442-457. doi:http://dx.doi.org/10.1016/j.foreco. 2012.11.007
Cumming GS. 2011. Spatial Resilience in Social-Ecological Systems. Springer Science \& Business Media.

del Moral R \& Grishin SY. 1999. Volcanic disturbances and ecosystem recovery. Dalam : Ecosystems of Disturbed Ground. Walker LR (Ed.). New York, USA: Elsevier. 137-160.

Drever CR, Peterson G, Messier C, Bergeron Y, \& Flannigan M. 2006. Can forest management based on natural disturbances maintain ecological resilience? Canadian Journal of Forest Research 36(9), 2285-2299. doi:10.1139/x06-132

Finegan B \& Camacho M. 1999. Stand dynamics in a logged and silviculturally treated Costa Rican rain forest, 1988-1996. Forest Ecology and Management 121(3), 177-189. doi:10.1016/S0378-1127(98)00550-7

Gunderson LH. 2000. Ecological resilience--In theory and application. Annual Review of Ecology and Systematics 31, 425-439. doi: $10.2307 / 221739$

He HS \& Mladenoff DJ. 1999. Spatially explicit and stochastic simulation of forest-landscape fire disturbance and succession. Ecology 80(1), 81-99. doi:10.1890/0012-9658(1999)080[0081: SEASSO]2.0.CO;2

Hessburg PF, Smith BG, \& Salter RB. 1999. Detecting change in forest spatial patterns from reference conditions. Ecological Applications 9(4), 1232-1252. doi:10.1890/1051-0761(1999)009[1232:DCIFSP ]2.0.CO;2

Hosonuma N, Herold M., de Sy V, de Fries R S, Brockhaus M, Verchot L, Angelsen A, \& Romijn E. 2012. An assessment of deforestation and forest degradation drivers in developing countries. Environmental Research Letters 7(4), 409.

Hughes TP, Bellwood DR, Folke C, Steneck RS, \& Wilson J. 2005. New paradigms for supporting the resilience of marine ecosystems. Trends in Ecology \& Evolution 20(7), 380-386. doi:http://dx.doi.org/10/1016/j.tree.2005.03.022

Jensen JR. 2005. Introductory digital image processing. a remote sensing perspective. Prentice Hall series in geographic information science.

Koppel J v. d. \& Rietkerk M. 2004. Spatial Interactions and Resilience in Arid Ecosystems. The American Naturalist 163(1), 113-121. doi:10.1086/380571 
Maintz T. 2005. Digital and medical image processing. Universiteit Utrecht.

Naveh Z. 2007. Landscape ecology and sustainability. Landscape Ecology 22(10), 1437-1440.

Nyström M \& Folke C. 2001. Spatial resilience of coral reefs. Ecosystems 4(5), 406-417. doi:10.1007/s10021-001-0019-y

Nyström M, Graham NAJ, Lokrantz J, \& Norström AV. 2008. Capturing the cornerstones of coral reef resilience: linking theory to practice. Coral Reefs 27(4), 795-809. doi:10.1007/s00338008-0426-z

Pickup G \& Foran B. 1987. The use of spectral and spatial variability to monitor cover change on inert landscapes. Remote Sensing of Environment 23(2), 351-363.

Richards JA. 2013. Remote Sensing Digital Image Analysis. Springer.

Rowlands G, Purkis S, Riegl B, Metsamaa L, Bruckner A, \& Renaud P. 2012. Satellite imaging coral reef resilience at regional scale. A case-study from Saudi Arabia. Marine Pollution Bulletin 64(6), 1222-1237. doi:http://dx.doi.org/ 10/1016/j.marpolbul.2012.03.003

Scheffer M, Carpenter S, Foley JA, Folke C, \& Walker B. 2001. Catastrophic shifts in ecosystems. Nature 413(6856), 591-596. Retrieved from http://dx.doi.org/10.1038/ $\underline{35098000}$

Wardhana W, Bomantara F, \& Sugiharto. 2011. Historical expansion of private forest in Gunungkidul Distric. Proceeding on Sustainable Development and Food Supply. Kyushu, Japan.

Washington-Allen RA, Ramsey R, West NE, \& Norton BE. 2008. Quantification of the ecological resilience of drylands using digital remote sensing. Ecology and Society 13(1), 33.

Wibowo SA. 2015. Prediksi Invasi Acacia decurrens Willd. Menggunakan Pemodelan Habitat Suitability Index (HSI) di Taman Nasional Gunung Merapi. Tesis (Tidak dipublikasikan), Fakultas Kehutanan, Universitas Gadjah Mada, Yogyakarta. 